\title{
Manifestation of anaplasmosis as cerebral infarction: a case report
}

\author{
Seok Won $\mathrm{Kim}^{1 \dagger}{ }^{1 \dagger}$ Choon-Mee Kim² ${ }^{2 \dagger}$ Dong-Min $\mathrm{Kim}^{3 *}$ (D) and Na Ra Yun ${ }^{3}$
}

\begin{abstract}
Background: Human granulocytic anaplasmosis is a tick-borne zoonotic disease caused by Anaplasma phagocytophilum, an obligate intracellular granulocytotropic bacterium.

Case presentation: A 70-year-old female patient was admitted with the clinical signs of fever and an altered state of consciousness 1 week after experiencing a tick bite while planting lawn grass. Magnetic resonance imaging, performed at the time of admission, indicated cerebral infarction in the left basal ganglia, whereas increasing immunofluorescence assay antibody titers for A. phagocytophilum were also documented. A. phagocytophilum was identified using groEL and ankA targeted polymerase chain reaction and sequencing. Because of severe thrombocytopenia, only doxycycline was administered, without any antiplatelet agents. Subsequently, the symptoms improved without any focal neurologic sequela.
\end{abstract}

Conclusion: This is the first reported case of cerebral infarction occurrence in an anaplasmosis patient.

Keywords: Anaplasmosis, Cerebral infarction, Human granulocytic anaplasmosis and Anaplasma phagocytophilum

\section{Background}

Human granulocytic anaplasmosis (HGA) refers to an acute febrile disease caused by the bite of the tick species Ixodes infected with Anaplasma phagocytophilum. In this condition, patients complain of various non-specific symptoms, including fever, chills, headache, and muscle ache [1]. Additionally, a wide range of symptoms, including vertigo, upper gastrointestinal bleeding, seizure, and confusion, have been reported in HGA patients [2].

Previously, there has been a reported case of cerebral infarction caused by macrovascular involvement in association with Mediterranean spotted fever caused by Rickettsia conorii [3], as well as cerebral hemorrhage or cerebral infarction in association with scrub typhus [4].

In general, the primary host cells of A. phagocytophilum are the granulocytes, particularly neutrophils. Previous studies have also demonstrated the infection in endothelial cells [5].

However, there have been no reported cases of cerebral infarction in HGA or ehrlichiosis patients to date.

\footnotetext{
* Correspondence: drongkim@chosun.ac.kr

† Seok Won Kim and Choon-Mee Kim contributed equally to this work.

${ }^{3}$ Departments of Internal Medicine, College of Medicine, Chosun University,

588 Seosuk-dong, Dong-gu, Gwangju 61453, Republic of Korea

Full list of author information is available at the end of the article
}

Here, we present a case of cerebral infarction that occurred in an HGA patient who was admitted for symptoms of fever and an altered state of consciousness after a tick bite.

\section{Case presentation}

A 70-year-old female patient was admitted for confusion. One week before admission, the patient discovered, while bathing, that she had been bitten by a tick that had attached to her skin while she was planting lawn grass earlier, and removed the tick accordingly. She reported that the tick was approximately $3 \mathrm{~mm}$ in size, but that she disposed of the tick after removal. Subsequently, there were no specific symptoms and she continued in planting lawn grass. However, 3 days after the tick bite, she began to develop dizziness with a fever. On the day of admission, she was waving her hands, was non-communicative, and provided irrelevant responses to questions. She appeared relatively fine while lying down, but, when standing up, the symptoms became severe and she struggled to maintain her balance. Therefore, she was admitted to the emergency room for further evaluation.

At the time of admission, a lesion suspected of being a tick bite with a diameter of approximately $5 \mathrm{~mm}$ was found in the right buttocks area (Fig. 1). Her blood pressure,

(c) The Author(s). 2018 Open Access This article is distributed under the terms of the Creative Commons Attribution 4.0 International License (http://creativecommons.org/licenses/by/4.0/), which permits unrestricted use, distribution, and 

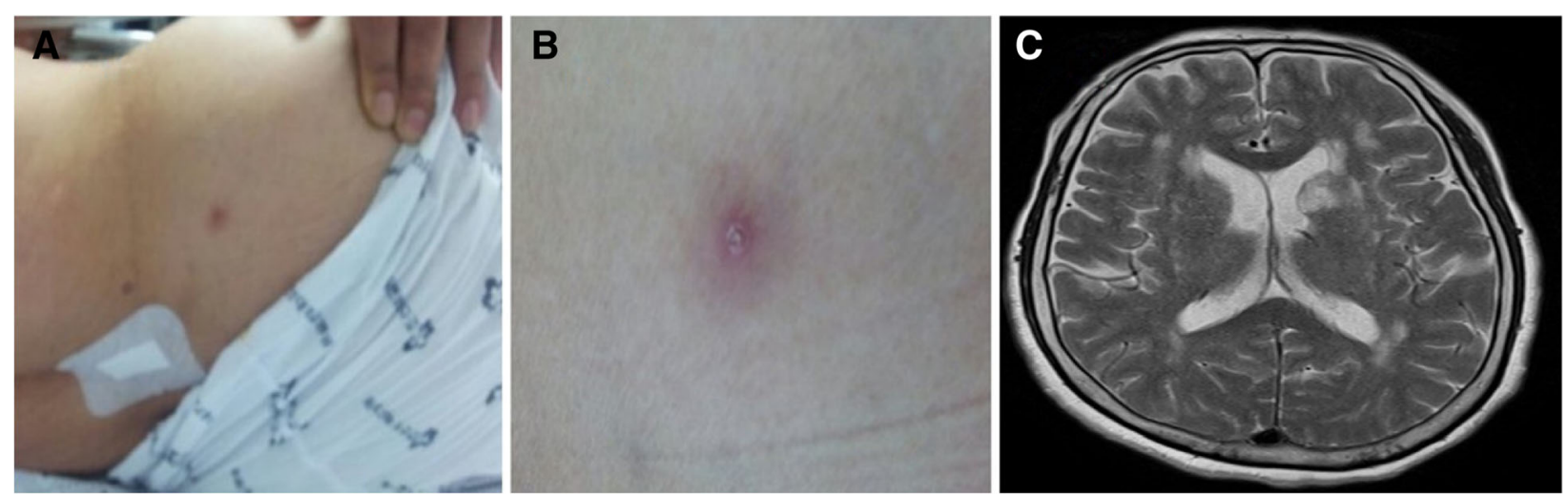

Fig. 1 A 70-year-old female patient with a confirmed diagnosis of human granulocytic anaplasmosis. a A lesion suspected of being a tick bite found on the right buttocks area at the time of admission. b Magnified image of the site of suspected tick bite. c Right middle cerebral artery territory infarction (recent onset infarction)on T2 -weightedimage on brain magnetic resonance imaging

pulse, respiratory rate, and body temperature at admission were 100/60 $\mathrm{mmHg}, 88$ beats/min, 24 breaths/min, and $38{ }^{\circ} \mathrm{C}$, respectively. Blood test results indicated a white blood cell (WBC) $920 / \mu \mathrm{L}$ (neutrophil 86.8\%), hemoglobin level of $14.1 \mathrm{~g} / \mathrm{dL}$, and platelet level of $22,000 / \mu \mathrm{L}$, whereas the biochemistry test results indicated: aspartate aminotransferase $99.9 \mathrm{IU} / \mathrm{L}$, alanine transaminase $54.7 \mathrm{IU} / \mathrm{L}$, total bilirubin $1.3 \mathrm{mg} / \mathrm{dL}$, blood urea nitrogen $20.1 \mathrm{mg} / \mathrm{dL}$, creatinine $0.67 \mathrm{mg} / \mathrm{dL}$, cholesterol $156 \mathrm{mg} / \mathrm{dL}$, and triglyceride $81 \mathrm{mg} / \mathrm{dL}$. Although the erythrocyte sedimentation rate was $7 \mathrm{~mm} / \mathrm{h}$, the C-reactive protein level was increased to $22 \mathrm{mg} / \mathrm{dL}$, whereas lactate dehydrogenase and creatine phosphokinase levels were elevated to 1052 (normal: 200450) U/L and 1394 (normal: 55-215) U/L, respectively. The blood coagulation test showed normal findings in prothrombin time $(10.7 \mathrm{~s})$, international normalized ratio (0.96), activated partial thromboplastin time (26 s), and fibrinogen $(384 \mathrm{mg} / \mathrm{dL})$, but elevated levels of fibrinogen degradation products (50.3 [normal: 0-5.0] $\mu \mathrm{g} / \mathrm{mL}$ ) and D-dimer (3199 [normal: 0-255] ng/mL). A lacunar infarction in the left basal ganglia was found during magnetic resonance imaging for determining the cause of the altered state of consciousness at the time of admission (Fig. 1); however, no significant stenosis or occlusion was found on magnetic resonance angiography. A cerebrospinal fluid (CSF) tap was performed to rule out encephalitis and meningitis, although there was no neck stiffness, with the results showing CSF WBC 0 per $\mathrm{mm}^{3}$, CSF protein $34.7 \mathrm{mg} / \mathrm{dL}$, and glucose $130.2 \mathrm{mg} / \mathrm{dL}$ (serum glucose $221.3 \mathrm{mg} / \mathrm{dL}$ ). No microorganisms were found in cultured blood and CSF using the BACTEC culture system (Becton Dickinson, Towson, MD, USA), whereas cerebral fluid herpes virus, enterovirus, Orientia tsutsugamushi, and Leptospira interrogans polymerase chain reaction all tested negative.

Although cerebral infarction in the left basal ganglia was identified, the patient exhibited low levels of platelets. Therefore, she was not qualified to receive antiplatelet agents. Furthermore, based on clinical signs of fever and altered state of consciousness after a tick bite, doxycycline $100 \mathrm{mg}$ twice daily was administered starting from post-admission day 2. The fever began to subside 1 day after doxycycline administration and resulted in the rapid resolution of symptoms. The patient showed a complete recovery of her consciousness by the 4th day of doxycycline administration.

A blood sample was tested using nested PCR with Anaplasma and Ehrlichia-specific primers targeting the GroEL heat-shock protein gene (groEL) and ankyrin-repeat protein AnkA gene $(\operatorname{ank} A)$, Additionally, a portion of the $16 \mathrm{~S}$ ribosomal RNA gene (16S rRNA) was amplified using PCR [6-8]. The PCR amplicons were purified and directly sequenced using PCR primers. BLAST (Basic Local Alignment Search Tool) analysis of sequenced productsconfirmed A. phagocytophilum infection (Fig. 2), although morulae were not detected in a stained peripheral blood smear.

Immunofluorescence assay (IFA) antibodies against $A$. phagocytophilum were also measured from the blood sample [8]. Upon admission, the immunoglobulin (Ig) M level was below 1:16 and the IgG level was below 1:80. At 7 days later, the IgM level was 1:64 and the IgG level was 1:320. The IFA examination using CSF showed an IgM level below 1:16 and an IgG level below 1:80.

Furthermore, other blood tests were negative for Hantavirus, severe fever thrombocytopenia syndrome virus, O. tsutsugamushi, and leptospirosis. Indirect IFA and reverse transcription-PCR were performed to diagnose hemorrhagic fever with renal syndrome and severe fever with thrombocytopenia syndrome in blood specimens, respectively [9-11]. Scrub Typhus RAPID kit (ImmuneMed, Republic of Korea) and $56-\mathrm{kDa}$ nested PCR were used for the diagnosis of scrub typhus [12]. Leptospira RAPID kit manufactured by ImmuneMed 

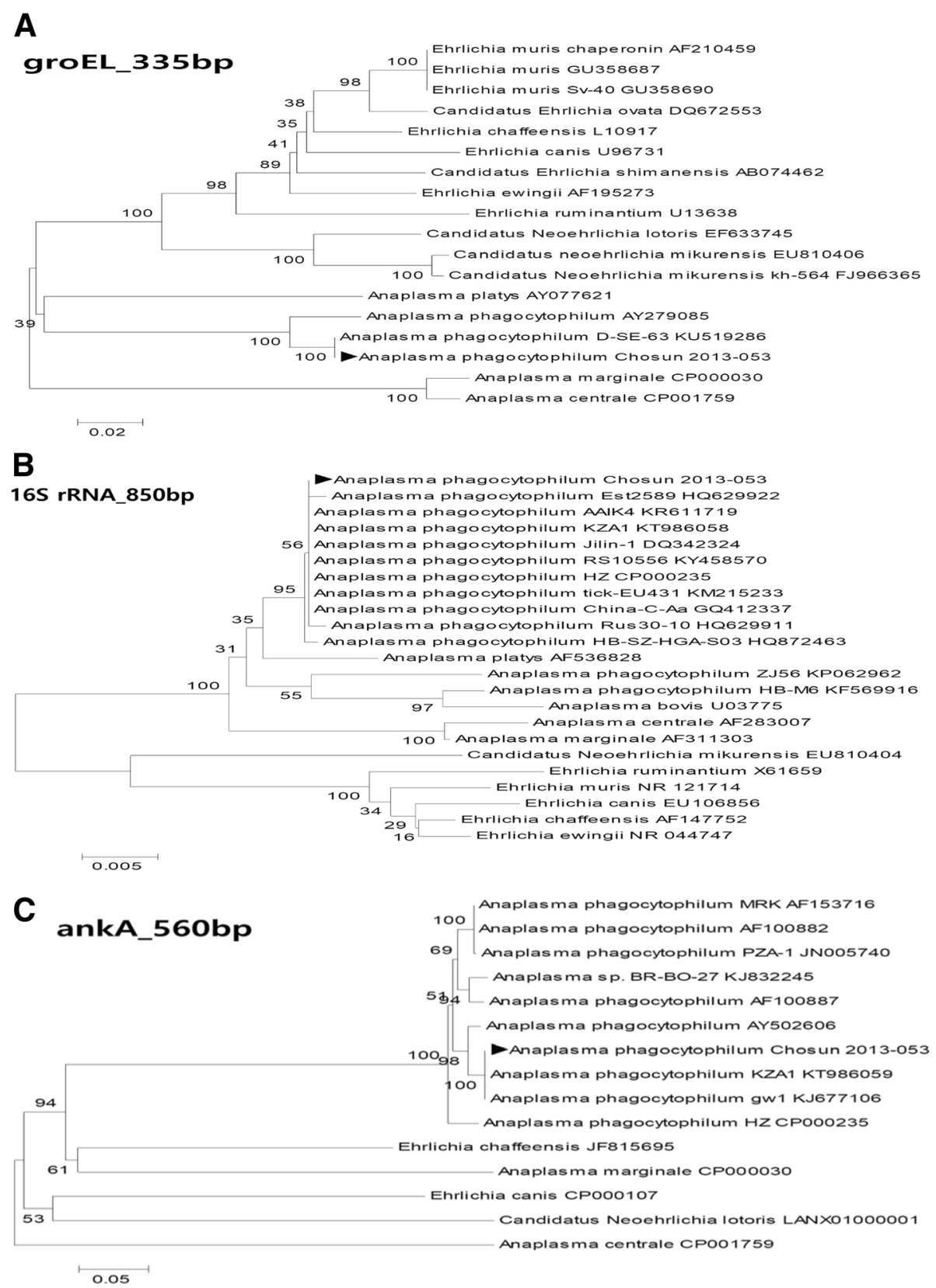

Fig. 2 Polymerase chain reaction (PCR) phylogenetic trees. The trees were generated using the buffy coat of a 70-year-old female human granulocytic anaplasmosis patient admitted for the chief complaint of fever. a Phylogenetic tree after groEL nested PCR. $\mathbf{b}$ Phylogenetic tree after 165 rRNA nested PCR. c Phylogenetic tree after AnkA nested PCR

(Republic of Korea) and hap1 nested PCR were used for the diagnosis of leptospirosis [13].

The patient exhibited an improvement in symptoms after doxycycline treatment and was discharged on the 12th day with no specific sequela.

\section{Discussion and conclusions}

HGA is a tick-borne zoonotic disease caused by $A$. phagocytophilum, an obligate intracellular granulocytotropic bacterium. To date, there have been no reported cases of cerebral infarction in an HGA patient. Such cases of thromboembolism have not been reported even in ehrlichiosis patients who show similar symptoms. However, portal vein and aortic thromboses were identified in a dog that contracted chronic ehrlichiosis with hypothyroidism, in which case improved clinical signs and diminished thrombi were reported after antibiotics treatment [14].

In addition, in a horse experimentally infected with $A$. phagocytophilum, an autopsy performed 2 days after death 
found widespread hemorrhage in the internal organs, along with vasculitis and thrombosis in the kidneys [15]. Another study in white footed mice showed extensive brain infection by Ehrlichia muris [16]; however, until now, there have been no reports on any HGA patients with thrombotic or embolic cerebral infarction. Secondary platelet dysfunction caused by an infectious disease results in platelet activation, coagulation, and, subsequently, prothrombotic state or reduced platelet function, which results in bleeding diatheses [17-19]. Platelets and A. phagocytophilum were incubated to cause platelet hypofunction, from which reduced responses to collagen, adenosine diphosphate, and epinephrine were reported. Such platelet dysfunction was dependent on the A. phagocytophilum dose, with a higher dose resulting in more severe alteration of function [20].

Autopsies on patients with Rocky Mountain spotted fever found non-occlusive fibrin thrombi in various organs, such as the gastrointestinal tract, pancreas, liver, kidney, and lung, and such thrombi were localized to rickettsia infection and vascular injury sites [5, 20, 21]. For A. phagocytophilum, the primary host cells are granulocytes and endothelial cells are also infected [5]. Accordingly, additional studies are deemed necessary to determine whether cerebral infarction occurred due to thrombosis brought on by endothelial cell injury caused by $A$. phagocytophilum, as in other rickettsia cases, or whether cerebral infarction occurred due to platelet dysfunction caused by $A$. phagocytophilum.

In conclusion, this case was the first reported case of cerebral infarction occurring in an anaplasmosis patient. As a clear resolution of clinical signs was achieved after doxycycline administration, anaplasmosis was believed to be the most likely cause of cerebral infarction.

\section{Abbreviations}

CSF: Cerebrospinal fluid; HGA: Human granulocytic anaplasmosis; IFA: Immunofluorescence assay; Ig: Immunoglobulin; PCR: Polymerase chain reaction; WBC: White blood cells

\section{Funding}

This study was supported by a grant of the Korean Health Technology R\&D Project, Ministry of Health \& Welfare, Republic of Korea (HI16C2118).

\section{Availability of data and materials}

All data generated or analysed during this study are included in this published article.

\footnotetext{
Authors' contributions

DMK designed and coordinated the study and contributed to drafting and reviewing the manuscript during the course of submission. SWK collected the patient's clinical data and pathologic data, wrote the manuscript, and revised the draft during the course of submission. CMK carried out the molecular analysis and immunofluorescence assay, wrote the manuscript, and also revised the draft during the course of submission. NRY was directly responsible for the patient and performed the clinical examinations, and helped in drafting the manuscript. All the authors read and approved the final version of the manuscript.
}

\section{Ethics approval and consent to participate}

The IRB of Chosun University approved this study. A written consent to participate in this study was obtained from the patient.

\section{Consent for publication}

Written informed consent was obtained from the patient upon discharge from the hospital for the publication of this case report and any

accompanying images. A copy of the written consent is available for review by the Editor of this journal.

\section{Competing interests}

The authors declare that they have no competing interests.

\section{Publisher's Note}

Springer Nature remains neutral with regard to jurisdictional claims in published maps and institutional affiliations.

\section{Author details}

${ }^{1}$ Department of Neurosurgery, College of Medicine, Chosun University, Gwangju, Republic of Korea. ${ }^{2}$ Premedical Science, College of Medicine, Chosun University, Gwangju, Republic of Korea. ${ }^{3}$ Departments of Internal Medicine, College of Medicine, Chosun University, 588 Seosuk-dong, Dong-gu, Gwangju 61453, Republic of Korea.

Received: 14 December 2017 Accepted: 9 August 2018

Published online: 17 August 2018

\section{References}

1. Sanchez E, Vannier E, Wormser GP, Hu LT. Diagnosis, treatment, and prevention of Lyme disease, human granulocytic Anaplasmosis, and Babesiosis: a review. JAMA. 2016:315(16):1767-77.

2. Bakken JS, Krueth J, Wilson-Nordskog C, Tilden RL, Asanovich K, Dumler JS. Clinical and laboratory characteristics of human granulocytic ehrlichiosis. JAMA. 1996;275(3):199-205.

3. Botelho-Nevers E, Foucault C, Lepidi H, Brouqui P. Cerebral infarction: an unusual complication of Mediterranean spotted fever. Eur J Intern Med. 2005;16(7):525-7.

4. Chung JH, Yun NR, Kim DM, Lee JW, Yoon SH, Kim SW. Scrub typhus and cerebrovascular injury: a phenomenon of delayed treatment? Am J Trop Med Hyg. 2013;89(1):119-22.

5. Rikihisa Y. Mechanisms of obligatory intracellular infection with Anaplasma phagocytophilum. Clin Microbiol Rev. 2011;24(3):469-89.

6. Takano A, Ando S, Kishimoto T, Fujita H, Kadosaka T, Nitta Y, Kawabata H, Watanabe $\mathrm{H}$. Presence of a novel Ehrlichia sp. in Ixodes granulatus found in Okinawa, Japan. Microbiol Immunol. 2009;53(2):101-6.

7. Oh JY, Moon BC, Bae BK, Shin EH, Ko YH, Kim YJ, Park YH, Chae JS. Genetic identification and phylogenetic analysis of Anaplasma and Ehrlichia species in Haemaphysalis longicornis collected from Jeju Island. Korea J Bacteriol Virol. 2009;39(4):257-67.

8. Kim CM, Kim SW, Kim DM, Yoon NR, Jha P, Jang SJ, Ahn YJ, Lim D, Lee SH, Hwang SD, et al. Case report: polymerase chain reaction testing of tick bite site samples for the diagnosis of human granulocytic Anaplasmosis. Am J Trop Med Hyg. 2017;97(2):403-6.

9. Ahn HJ, Chung JH, Kim DM, Yoon NR, Kim CM. Hemorrhagic fever with renal syndrome accompanied by panhypopituitarism and central diabetes insipidus: a case report. J Neuro-Oncol. 2018;

10. Song JY, Chun BC, Kim SD, Baek LJ, Kim SH, Sohn JW, Cheong HJ, Kimt WJ, Park SC, Kim MJ. Epidemiology of hemorrhagic fever with renal syndrome in endemic area of the Republic of Korea, 1995-1998. J Korean Med Sci. 2006;21(4):614-20

11. Park SW, Han MG, Yun SM, Park C, Lee WJ, Ryou J. Severe fever with thrombocytopenia syndrome virus, South Korea, 2013. Emerg Infect Dis. 2014;20(11):1880-2.

12. Kim CM, Cho MK, Kim DM, Yun NR, Kim SW, Jang SJ, Ahn YJ, Lim D. Accuracy of conventional PCR targeting the 16S rRNA gene with the Ot16sRF1 and Ot-16sRR1 primers for diagnosis of scrub typhus: a case-control study. J Clin Microbiol. 2016;54(1):178-9.

13. Branger C, Blanchard B, Fillonneau C, Suard I, Aviat F, Chevallier B, AndreFontaine $G$. Polymerase chain reaction assay specific for pathogenic Leptospira based on the gene hap1 encoding the hemolysis-associated protein-1. FEMS Microbiol Lett. 2005;243(2):437-45. 
14. Bressler C, Himes LC, Moreau RE. Portal vein and aortic thromboses in a Siberian husky with ehrlichiosis and hypothyroidism. J Small Anim Pract. 2003:44(9):408-10.

15. Franzen P, Berg AL, Aspan A, Gunnarsson A, Pringle J. Death of a horse infected experimentally with Anaplasma phagocytophilum. Vet Rec. 2007;160(4):122-5.

16. Lynn GE, Oliver JD, Cornax I, O'Sullivan MG, Munderloh UG. Experimental evaluation of Peromyscus leucopus as a reservoir host of the Ehrlichia muris-like agent. Parasit Vectors. 2017;10(1):48.

17. Elizalde Jl, Gomez J, Panes J, Lozano M, Casadevall M, Ramirez J, Pizcueta P, Marco F, Rojas FD, Granger DN, et al. Platelet activation in mice and human helicobacter pylori infection. J Clin Invest. 1997;100(5):996-1005.

18. Russell KE, Perkins PC, Hoffman MR, Miller RT, Walker KM, Fuller FJ, Sellon DC. Platelets from thrombocytopenic ponies acutely infected with equine infectious anemia virus are activated in vivo and hypofunctional. Virology. 1999;259(1):7-19

19. Borjesson DL, Brazzell JL, Feferman R. Platelet dysfunction after association with Anaplasma phagocytophilum in vitro. Ann N Y Acad Sci. 2005;1063:413-5.

20. Schmaier AH, Srikanth S, Elghetany MT, Normolle D, Gokhale S, Feng HM, Walker DH. Hemostatic/fibrinolytic protein changes in $\mathrm{C} 3 \mathrm{H} / \mathrm{HeN}$ mice infected with rickettsia conorii--a model for Rocky Mountain spotted fever. Thromb Haemost. 2001;86(3):871-9.

21. Walker DH, Mattern WD. Acute renal failure in Rocky Mountain spotted fever. Arch Intern Med. 1979;139(4):443-8.

Ready to submit your research? Choose BMC and benefit from:

- fast, convenient online submission

- thorough peer review by experienced researchers in your field

- rapid publication on acceptance

- support for research data, including large and complex data types

- gold Open Access which fosters wider collaboration and increased citations

- maximum visibility for your research: over $100 \mathrm{M}$ website views per year

At $\mathrm{BMC}$, research is always in progress.

Learn more biomedcentral.com/submissions 